\title{
Paleomedicine and the Evolutionary Context of Medicinal Plant Use
}

\author{
Karen Hardy ${ }^{1,2}$ (D) \\ Received: 8 September 2020 / Accepted: 23 September 2020 / Published online: 9 October 2020 \\ (C) Sociedade Brasileira de Farmacognosia 2020
}

\begin{abstract}
Modern human need for medicines is so extensive that it is thought to be a deep evolutionary behavior. There is abundant evidence from our Paleolithic and later prehistoric past, of survival after periodontal disease, traumas, and invasive medical treatments including trepanations and amputations, suggesting a detailed, applied knowledge of medicinal plant secondary compounds. Direct archeological evidence for use of plants in the Paleolithic is rare, but evidence is growing. An evolutionary context for early human use of medicinal plants is provided by the broad evidence for animal self-medication, in particular, of non-human primates. During the later Paleolithic, there is evidence for the use of poisonous and psychotropic plants, suggesting that Paleolithic humans built on and expanded their knowledge and use of plant secondary compounds.
\end{abstract}

Keywords Human self-medication $\cdot$ Medicinal plants $\cdot$ Paleolithic $\cdot$ Psychoactive plants $\cdot$ Raw materials

\section{Introduction}

Humans love medicines (Sullivan et al. 2010). Expenditure on pharmacological drugs was US $\$ 455.9$ billion in the USA in 2017 (Schumock et al. 2017) while global spending on pharmaceuticals was a startling US $\$ 1.25$ trillion in 2019 (Mikulic 2020). Many modern human groups in traditional societies continue to rely heavily on their pharmaceutical knowledge of wild plants and demonstrate astounding levels of knowledge, for example in New Guinea, use of 1035 plant species was recorded in the 1970s, of which 332 species from 99 different families were used specifically for their medicinal compounds (Powell 1976). Still, in 2002, over $80 \%$ of people in developing countries continued to rely on plants for their medicinal requirements (Ssegawa and Kasenene 2007).

The extent of the human desire for medicines suggests this may be an evolutionary behavior (Johns 1990; Sullivan et al. 2010), while a study of some modern medicinal plants that linked the useful medicinal compounds of certain plants to the way they were used in three separate regions of the world

Karen Hardy

khardy@icrea.cat

1 Institució Catalana de Recerca i Estudis Avançats, Pg. Lluís Companys 23, 08010 Barcelona, Catalonia, Spain

2 Departament de Prehistòria, Facultat de Filosofia i Lletres, Universitat Autònoma de Barcelona, Bellaterra, 08193 Barcelona, Catalonia, Spain provides an indication of the antiquity and efficacy of their use (Saslis-Lagoudakis et al. 2012). However, searching for evidence of use of medicines in the archeological record is challenging; plant remains only rarely survive into the deep Paleolithic past, and when they do survive, it can be hard to demonstrate deliberate medicinal application. The only other way to obtain direct empirical evidence for the use of medicinal plants is through recovery and analysis of biomolecular compounds that can be present in residual material such as human dental calculus or on artifacts, such as bags, pots, or tools. In order to reach an approximation of the likelihood of selfmedication in the deep human past, we need to look at the broader, evolutionary context.

The Paleolithic began some 3.4 million years ago coinciding with the earliest evidence of manufactured stone tools. During the Lower (3.4 million-300,000 years ago) and Middle Paleolithic (300,000-45,000 years ago) periods, the world was occupied by several hominin species (Homo spp.). Evidence for these has been found in Africa, Asia, and Europe. In the Middle Paleolithic, Neanderthals occupied Europe, Central and South West Asia, and southern Siberia while evidence for another species or subspecies of hominin, Denisovans, has been found across Asia during this period (Douka et al. 2019; Reich et al. 2010, 2011). At approximately the same time period, in Africa, the Middle Stone Age population comprised archaic and modern Homo sapiens. H. sapiens spread from Africa, reaching South West Asia around 100,000 years ago, Europe around 45,000 years ago, through South East Asia and into Australia by 50,000 years ago 
(Dennell 2020). Neandertals ultimately disappeared around 39,000 years ago (Higham et al. 2014) though some interbreeding had occurred with the local $H$. sapiens population (Sankararaman et al. 2012). The timing of the colonization of America remains unclear though it is thought to have occurred at some point during the last glacial period when lower sea levels exposed the Bering land bridge between Siberia and Alaska (Braje et al. 2017; Moreno-Mayar et al. 2018).

Here, I will outline the archeological evidence for successful treatment of medical problems and for use of medicinal, poisonous, and psychoactive plant in the prehistoric past. I will then summarize the broad evolutionary context of early human self-medication and end by discussing the implications of this and its relationship with modern human behavior.

\section{Discussion}

\section{Physical Evidence for Successful Treatment of Ailments}

Reconstructing the past using archeology is an inexact science that relies on recovery of partial evidence in the form of unquantifiable archeological remains, making the role of context of primary importance. An example of this can be found at the 19,000-year-old site of Ohalo II, Israel, where a brushwood hut was reconstructed, based on the archeological association of the charred remains of branches and leaves that formed the shape of an oval structure, within which many materials such as piles of fishbones and a grinding stone were found (Nadel and Werker 1999). Human bones are a good source of information from the past and the prehistoric archeological record is rich in evidence for accidents, illnesses, and trauma and for survival of individuals with pathologies, including among Paleolithic populations. These include dental issues, abscesses, and many different types of injuries, including blunt force injuries and bone fractures, osteoarthritis, periostitis, and wounds (Spikins et al. 2019). The earliest archeological evidence for long-term survival of a visibly non-optimum individual in the human evolutionary past is from Dmanisi, Georgia. This individual, who was a member of a subspecies of Homo erectus, lived around 1.7 million years ago and survived for several years having suffered periodontal disease and lost all their teeth (Lordkipanidze et al. 2005). If periodontal disease is not treated, it can cause brain abscesses as well as cardiovascular disease and some cancers. The survival of this individual may have been down to extraordinary luck, but the use of antibacterial plants may well have saved them. There is abundant evidence for dental problems throughout the archeological record and attempts at treating these currently represent the earliest evidence for invasive medical treatment. From Homo habilis (2.4-1.6 million years) onwards, there are many examples of interproximal grooves, or deep scratches in teeth that have been interpreted as evidence for tooth picking (Ungar et al. 2001; Gracia-Téllez et al. 2013; Lozano et al. 2013; Sun et al. 2014). This is supported by the presence of non-edible wood fragments, recovered from the dental calculus of Paleolithic individuals in association with interproximal grooves from the 1.2-million-year-old hominin from Sima del Elefante, Spain (Hardy et al. 2017), and an example from a 49,000-year-old Neanderthal from El Sidrón, Spain (Hardy et al. 2012). Here, the wood fragment was found adjacent to evidence for a tooth abscess (Radini et al. 2016). A Neanderthal individual from the site of Krapina in Croatia, and dated to around 130,000 years ago, has evidence for interproximal grooves as well as dental probing on several teeth. These are thought to be linked to the evident dental problems including rotation and fractures, seen in the teeth of this individual (Frayer et al. 2017). Further evidence for dental treatment can be found in the Late Upper Paleolithic where scraping inside a dental carious lesion, suggesting invasive treatment, was identified in a skeleton dating to around 14,000 years ago (Oxilia et al. 2015).

One of the best-known groups of Neanderthals to display evidence for survival following trauma is from Shanidar, Iran, where four individuals some of relatively advanced age, and dated to between 65,000 and 35,000 years ago, had suffered a range of injuries from which they had recovered and lived, sometimes for several years, with little obvious after-effects of infection (Trinkaus and Zimmerman 1982). It is unlikely this could have occurred without use of antibacterial plants. Near the graves at Shanidar, clusters of pollen from several plants, including a member of the genus Ephedra, Ephedraceae, identified as having significant medicinal properties, led to the suggestion that these had been deliberately placed (Solecki 1975; Leroi-Gourhan 1975); however, whether the plants were intentionally deposited is doubtful as it could be due to rodent activity (Sommer 1999). Of the bioactive alkaloids found in Ephedra (at concentrations of $0.02-3.4 \%$ ), the most common is ephedrine (1); these ephedrinetype alkaloids are responsible for the stimulant and thermogenic effects of the crude drug, which also included antioxidant and antimicrobial properties (Elhadef et al. 2020).

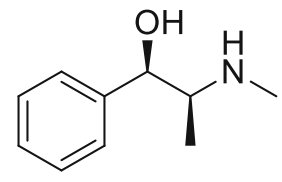

1

Surgical procedures from which individuals have recovered, including amputation and trepanation, are relatively common in later prehistory. The earliest known healed trepanation was detected on a 50-year-old male from the site of Vasilyevka II, Ukraine, and dates to the Mesolithic (late hunter gatherer) period around 8020-7620 years ago (7300-6220 BC) (Lillie 1998) while further examples from the subsequent Neolithic period 
have been recorded (Alt et al. 1997). A well-healed double skull trepanation on an individual from Italy, dated to 5000 years ago, is thought to have been conducted to treat chronic osteomyelitis (Petrone et al. 2015). Altogether, there are approximately 1500 examples of trepanation in the prehistoric archeological record (Faria 2015). Most of these are found in Andean South America where over 1000 examples have been identified (Verano 2003). Currently, the oldest known example of an individual who survived amputation of the left arm, as demonstrated by healed cicatrices, is from the Neolithic site of Buthiers-Boulancourt, France, almost 7000 years ago (4900-4700 BC) (Verano et al. 2000; Buquet-Marcon et al. 2007). The evident complexity of some surgical procedures and the many examples of healing after trauma and overcoming infections suggests a mastery in the use of medicinal plants.

As well as the pain these would cause, any form of injury, from a broken bone to a small scratch, a lost tooth, or a burn as well as internal infections resulting from food poisoning, urinary tract infections, ie pneumonia, if untreated, can lead to tetanus, septicemia, acute respiratory distress syndrome, and sepsis. All of these can rapidly become life-threatening. Likewise, there is a vast number of human pathogens comprising viruses, bacteria, fungi, and prions that can cause disease in humans. Current wellknown viruses include HIV, Ebola, and Covid-19, all of which affect modern human populations. In the relatively recent past, the Variola spp. (smallpox) virus, together with others including measles (rubeola), decimated around $90 \%$ of the Native American population (Roberts 1989). The bacterium Yersinia pestis, which caused three major outbreaks of bubonic plague between $\mathrm{AD} 541$ and the early part of the twentieth century, killed hundreds of millions of people (Benedictow and Benedictow 2004; Wagner et al. 2014; Mordechai et al. 2019). Though bacteria are more virulent in warmer environments, the temperature range at which most are active is between 5 and $60{ }^{\circ} \mathrm{C}$ which encompasses most of the hominin (Paleolithic period Homo spp.) inhabited zones. Additionally, parasites such as the Plasmodium parasite that causes malaria as well as a wide range of intestinal parasites also have high levels of morbidity if not treated while gastroenteritis, which affected around 2 billion people and caused approximately 1.3 million deaths worldwide in 2015 (Vos et al. 2016), is caused by a range of viruses, bacteria, parasites, and fungi. While humans are still unable to withstand some pathogens, it is unlikely that the hominin lineage could have survived without mechanisms to control at least some of these, as many animal species do.

\section{Archeological Evidence for Use of Secondary Metabolites}

\section{Medicines}

The presence of animal produce in close contact with living areas, which is found almost universally on Paleolithic sites, suggests that these were ripe environments for pathogens though, until recently, detection of illness in Paleolithic populations has largely been restricted to skeletal evidence. Now, DNA analyses of dental calculus have begun to identify pathogenic bacteria among past populations. The use of medicinal plants is likely to have formed an integral part of Paleolithic life, though recovering evidence for this is rare (Hardy 2018, 2019). Hardy et al. (2012) extracted biomolecular evidence for two volatile oil-rich plants from the family Asteraceae, Achillea millefolium L. (common yarrow) and Matricaria chamomilla (L.) Rydb. (chamomile), both of which have medicinal but no nutritional properties, from the dental calculus of a 49,000-year-old Neanderthal individual from El Sidrón, north Spain, by using sequential thermal desorption-gas chromatography-mass spectrometry and pyrolysis-gas chromatography-mass spectrometry (Fig. 1). This dental calculus sample was particularly notable for the presence of azulene and coumarin derivatives. The presence of chamazulene (2) is remarkable since, together with herniarin (3), it occurs in yarrow and chamomile. Chamazulene is an artifact formed from matricin (4), a sesquiterpene lactone present in the flowers. These compounds are responsible, in conjunction with polyphenols and flavonoids, for the anti-inflammatory and bactericidal effect of the raw material (Singh et al. 2011).

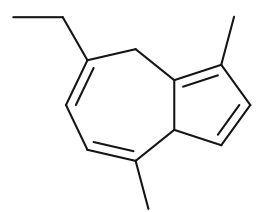

2<smiles>COc1ccc2ccc(=O)oc2c1</smiles>

3

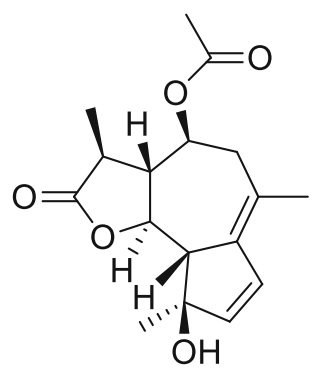

4

In a subsequent study that analyzed the DNA preserved in the dental calculus from the same individual, Weyrich et al. (2017) identified a parasite that causes acute diarrheal infections (Enterocytozoon bieneusi) and several pathogenic oral microbial species in association with the visible signs of a dental abscess. Weyrich et al. (2017) also recovered DNA evidence for further plants with medicinal properties including a species of poplar, Populus trichocarpa Torr. \& A. Gray ex Hook., Salicaceae, as well as plant fungal pathogens including Penicillium rubens, suggesting that the individual might have been treating the abscess, while a significant presence of the 
Fig. 1 Reconstructed total ion chromatogram of the pyrogram (pyrolysis profile $\left(610^{\circ}\right.$ for 10$)$ after thermal desorption $\left(310^{\circ}\right.$ for $10 \mathrm{~s}$ ). Peak identities (x indicates carbon chain length): filled diamonds, $\mathrm{Cx}: 0$ indicates saturated fatty acid methyl esters; filled squares, $\mathrm{Cx}$ indicates alkenes; filled circles, $\mathrm{Cx}$ indicates alkanes; inverted triangles, $a$ is fluoranthene and $b$ is pyrene. $\mathrm{Ph}$ is phytane and $\mathrm{Pr}$ is pristane. Peak 1 is 2-methyl-2cyclopenten-1-one and 2 is 2,3 dimethyl-2-cyclopentene-1-one. Insert displays a reconstructed total ion chromatogram of the thermal desorption profile (reproduced from Hardy et al. 2012)

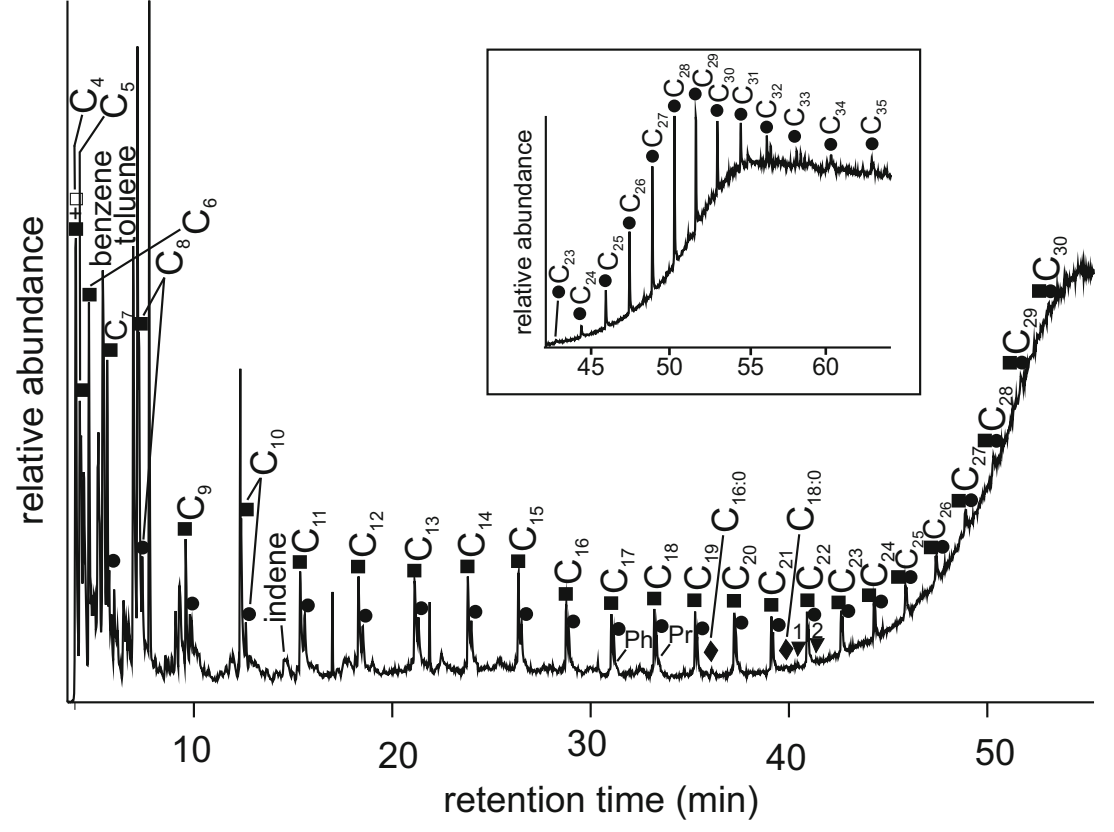

mushroom Coprinopsis cinerea that has antibiotic properties, in a Neanderthal individual from the site of Spy II, in Belgium is also suggestive of self-medication. However, in many cases, the boundary between "food" and "medicine" is unclear, and where plants have both medicinal and edible properties, identification of the use of these for their medicinal properties is challenging. Yet when something unexpected has been ingested, we can ask why and try to find the best fit. While we cannot "prove" the plants were ingested for medicinal purposes, when viewed within the evolutionary and archeological contexts for self-medication (Hardy et al. 2013, 2016), the evidence can be compelling. For example, the correlation between the presence of the intestinal and oral pathogens, a tooth abscess (Weyrich et al. 2017) and consumption of medicinal plants, and fungi with antibacterial, antiseptic, and anti-inflammatory properties in the El Sidrón individual, strongly suggests that these are all linked, particularly since none of the identified plants has any nutritional properties.

Samples of dental calculus from the multiperiod site of $\mathrm{Al}$ Khiday, in Sudan, were degraded to extract chemical compounds (Buckley et al. 2014). These revealed a consistent presence of Cyperus rotundus L., Cyperaceae, a plant that is both edible and has abundant medicinal properties. Interestingly, this site covers the period in which agriculture was introduced and replaced hunting and gathering as the predominant food collection strategy. Yet, the use of C. rotundus continued and, though it is a good source of carbohydrates, the new agricultural plants would have largely replaced this with more easily accessible availability of these essential macronutrients. Among the useful medicinal properties of the tubers of $C$. rotundus is the ability to inhibit
Streptococcus mutans, a leading source of tooth decay ( $\mathrm{Yu}$ et al. 2007; Khojaste et al. 2018). There was an unusually low level of dental caries in the population of Al Khiday, and the broad consumption of $C$. rotundus may have wittingly, or unwittingly, contributed to this (Buckley et al. 2014). The antibacterial properties of the tubers are a consequence of the identified flavonoids and sesquiterpenes, e.g., rotundone (5).

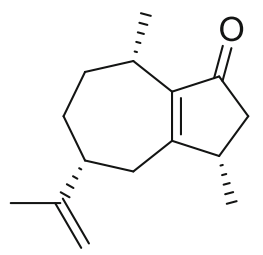

5

The Late Upper Paleolithic site of Taforalt, Grotte des Pigeons, Morocco, is renowned for the serious oral pathologies of virtually all individuals, as well as its abundant remains of starchy plant foods dating to between 15,100 and 14,000 years ago (Humphrey et al. 2014). All of the most common plants recovered at the site are rich sources of starchy carbohydrates and the abundance of their remains suggests that consumption of these may have been a cause for the bad state of the inhabitants' teeth. However, another plant that was also abundant on the site is Juniperus phoenicea L., Cupressaceae; while also a source of starchy carbohydrates, it is also rich in the sesquiterpene, thujopsene (6), that has important antifungal, antiseptic, and anti-inflammatory properties. Though it did not cure the people of their dental health problems, it is likely that this plant was used to alleviate some of their symptoms (Hardy 2019). 
<smiles>CC1=CC[C@@]2(C)CCCC(C)(C)[C@]12C</smiles>

6

More broadly, a study of a small number of Paleolithic sites that have significant plant assemblages demonstrated consistently that the wide variety of species present cannot be explained solely as food (Hardy 2019). Only plant remains that could be identified to species level were included in the study, and these were divided into three categories: plants that were edible with no significant medicinal properties, plants that had both edible and medicinal properties, and plants that had only medicinal properties (and could also be poisonous). An analysis of the plant remains from the archeological contexts of five Paleolithic sites (Gesher Benot Ya'aqov (GBY) 780,000 years ago, Kebara, 60-48,000 years ago, Ghar e Boof, 33-30,000 years ago, Ohalo II 23-19,000 years ago, Abu Hureyra, 31-9000 years ago, Netiv Hagdud, 11,00010,000 years ago, Atlit Yam, 10,500-8000 years ago) has shown that there is a far higher proportion of plants containing important medicinal properties than would be present in a natural distribution (Fig. 2). An example is the milk thistle, Silybum marianum (L.) Gaertn., Asteraceae, renowned for its use today to treat liver problems, and present at three sites (GBY, Ohalo II, Atlit Yam) (Fig. 3). The proportion of plants that had only medicinal (and potentially poisonous) properties ranged from 6 to $33 \%$, rising significantly at the start of the Neolithic period 11-9000 years ago, suggests more extensive mechanisms for social transmission at this time (Fig. 4).

After the Paleolithic, there is more evidence of both survival with pathologies and, in some exceptional cases, actual remains of medicinal plants. The mummified body of a 4500-year-old man, thought to be around 40-50 years old when he died, was found in 1991 in the Italian Alps (Gaber and Künzel 1998). Nicknamed Ötzi, he had multiple

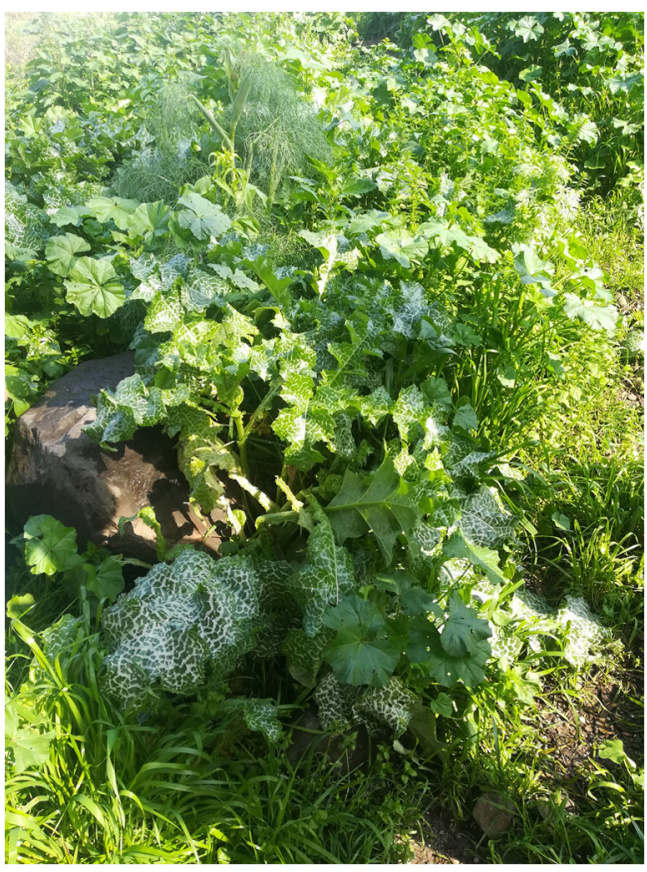

Fig. 3 Silybum marianum (L.) Gaertn., Asteraceae. Image taken at the 780,000-year-old site of Gesher Benot Ya'aqov (GBY), Israel, February 2019. Many of the plants found in the archeological site are present today in the surrounding area

pathologies, including periodontitis, healed rib fractures, intestinal parasites, and gall stones. He also had some degenerative joint disease, mild osteoarthritis, and a healed broken rib as well as several peri-mortem injuries (Zink et al. 2019). Sixty-one tattoos in nineteen groups were found on his body (Samadelli et al. 2015), all related to known acupuncture points suggesting preventative medicinal measures, while fragments of plants, including the bracken fern Pteridium aquilinum (L.) Kuhn, Dennstaedtiaceae (treatment: intestinal parasites), several mosses including Sphagnum imbricatum Hornsch. ex Russow., Sphagnaceae (treatment: wound dressing) and fungi like birch polypore, Piptoporus betulinus (Bull.) P. Karst., Fomitopsidaceae (anti-inflammatory and
Fig. 2 Proportions of plants with medicinal compounds from Paleolithic sites, against modern averages (data taken from Hardy 2019)

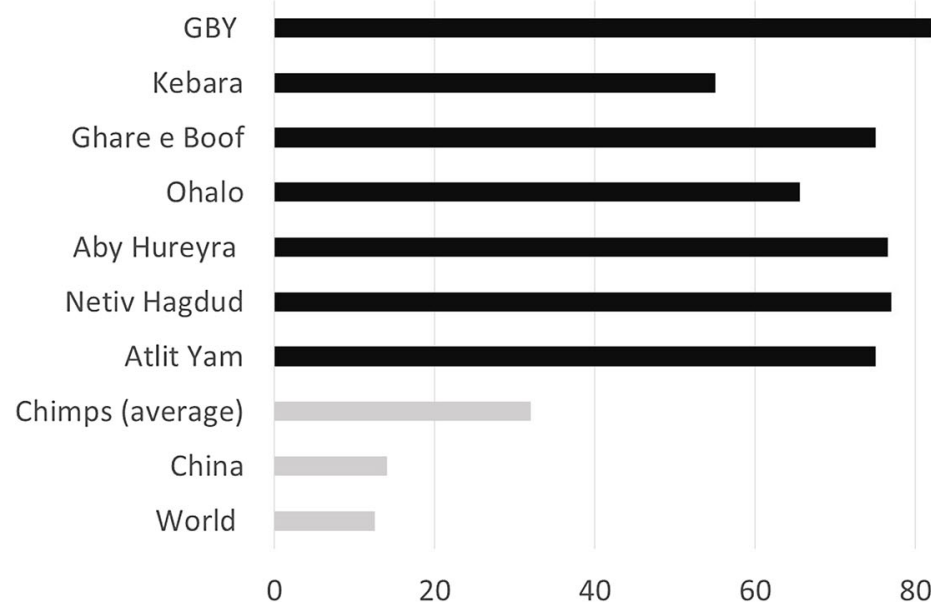


Fig. 4 Relative proportions of plants with edible, edible and medicinal, and medicinal (and sometimes poisonous) plants, over time (data taken from Hardy 2019)

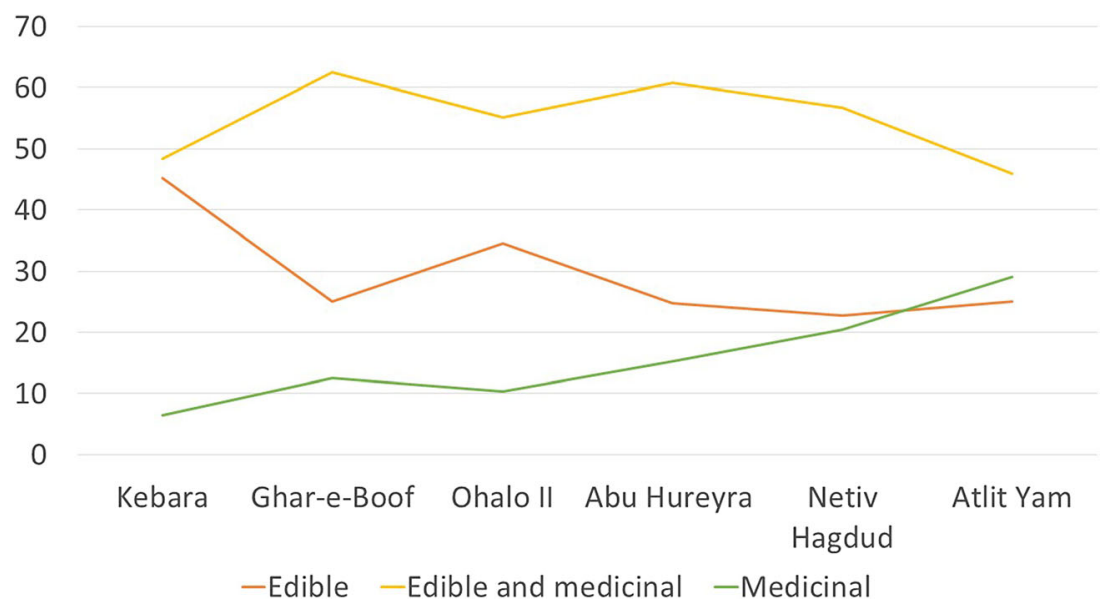

antibiotic properties) were found either as part of his equipment or in his stomach and are thought to have been used as medicines (Zink et al. 2019). The very detailed study of this mummified individual has provided a unique insight into the extent of both preventative and curative medicine from the Bronze Age (Fig. 5).

One of the earliest sites in the American continent is Monte Verde, in Chile, that was occupied from at least 18,50014,500 years ago (Dillehay et al. 2015). This site has a large assemblage of carbonized plants, of which a significant number, including several species of seaweed, are thought to have been collected for their medicinal properties while the remains of a structure are thought to be a medicinal hut (Dillehay 1997, Dillehay et al. 2008, Dillehay et al. 2015). Traces of the medicinal San Pedro cactus, Echinopsis pachanoi (Britton \& Rose) Friedrich \& G.D. Rowley, Cactaceae, were found at Guitarrero Cave, Peru, and dated to around 10,000 years ago (8600-5600 BC; Lynch 1980). Medicinal uses including treatment for ulcers, wounds, inflammation acne, and fortifying hair have been recorded ethnographically (Bussmann and Sharon 2006; Paniagua-Zambrana and Bussmann 2020), and it also has hallucinogenic properties (Guerra-Doce 2015) due to its high content of mescaline (7), a protoalkaloid of the substituted phenethylamine class.<smiles>COc1cc(CCN)cc(OC)c1OC</smiles>

7

Reinhard et al. (1991) developed the use of pollen extracted from human coprolites to develop studies of paleopharmacology from North and South American archeological sites. The use of pollen as evidence of deliberate plant ingestion is complex, since it occurs as "rain" and can be environmental; however, high
Fig. 5 Tyrolean Iceman (Ötzi). (C) South Tyrolean Museum of Archaeology/EURAC/Marco Samadelli-Gregor Staschitz. Injuries, ailments, and tattoos found on the frontal upper body (data taken from Zink et al. 2019 and Samadelli et al. 2015)

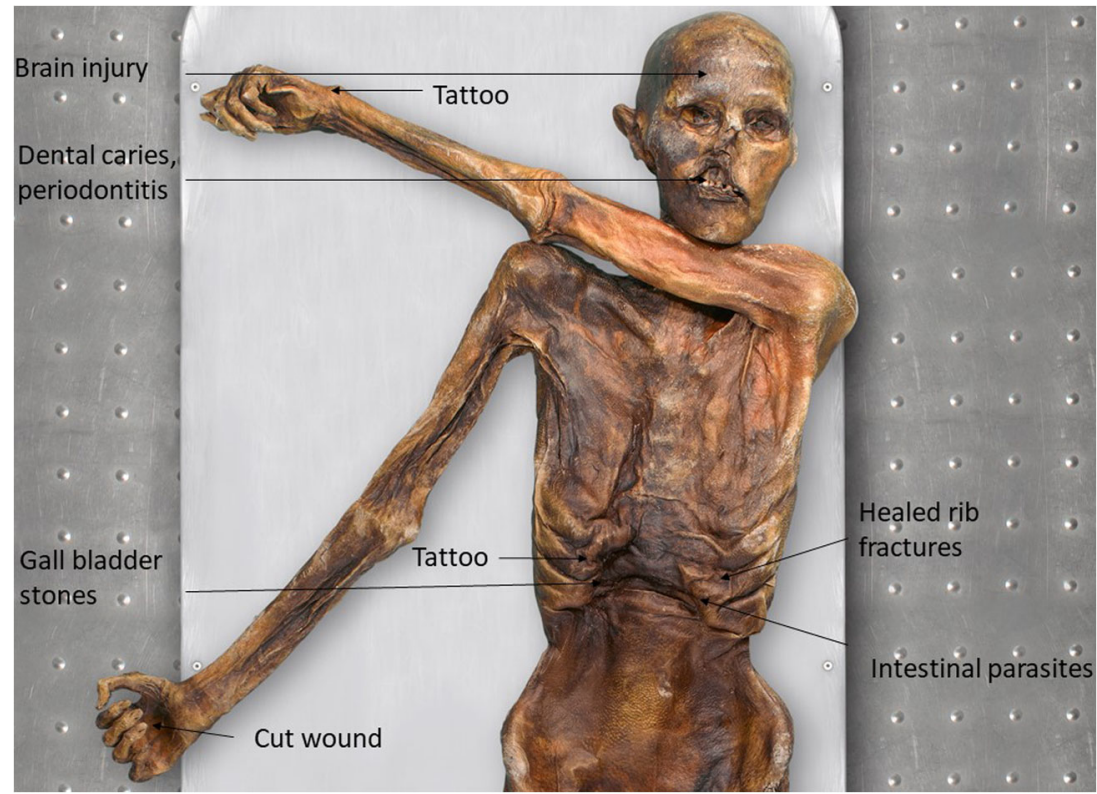


concentrations are suggested to indicate intentional consumption (Reinhard et al. 1991). Using this method, several studies of prehistoric and pre-Hispanic populations in the American continent have identified possible ingestion of a range of medicinal plants, sometimes in association with evidence for intestinal parasites. Examples include sites in North America (Reinhard et al. 1991) (Ephedra sp., Larrea sp., Salix sp.; Sobolik and Gerick 1992, Ephedra sp., Prosopis sp.), and South America, including Furna do Estrago, Pernambuco State, Brazil (several plants including Stryphnodendron adstringens (Mart.) Coville, Fabaceae, or barbatimão) and a range of genera including, Sida sp., Sebastiania sp., and Fevillea sp. (Teixeira-Santos et al. 2015) and Pedra Furada, in the State of Piauí, Brazil, where twelve taxa from genera that include medicinal plants were identified (de Miranda Chaves and Reinhard 2006). The low levels of the otherwise very common intestinal parasites Ascaris lumbricoides (giant roundworm) and Trichuris trichiura (whipworm) in some South American prehistoric populations have led to the suggestion that this may be due to the use of medicinal plants (Leles et al. 2010).

Some of the earliest texts known concern medical practices and the use of plants as medicine. Six papyri from Egypt, dating to between 2000 BC and 1500 BC (Frey 1985), display an extensive knowledge with around 160 different medicinal plants identified (Ritner 2000). Hundreds of thousands of medical texts from Mesopotamia were written mostly on clay tablets in cuneiform and date to the 3rd millennium BC (Robson 2008; Retief and Cilliers 2007). Medicinal plants are discussed in the Atharvaveda (Bloomfield 1899), an Indian text written around $1200 \mathrm{BC}$ in Sanskrit. The first known Chinese medicine text is the Huangdi Neijing dated to the third century BC (Cavalieri and Rotoli 1997) though Chinese medicine is considered to be at least 4500 years old (Wong and $\mathrm{Wu}$ 1932) while the earliest text in Japan is the Ishimpō, a 30-volume text completed in $984 \mathrm{CE}$ (Tamba 1986). Early Greek medicine was strongly focused on medicinal plants (Prioreschi 1996). De Materia Medica, a fivevolume work comprising descriptions of over 600 medicinal plants was written between 50 and $70 \mathrm{CE}$ by Pedanius Dioscorides, a Greek physician in the Roman Army, while the Hippocratic Oath which dates to around $275 \mathrm{CE}$ is still used today (Hulkower 2016). Medicinal plants, specifically those with anthelmintic or anti-parasite properties, have been identified in several colonial manuscripts including the XVI century Aztec herbal, The Badianus Manuscript (Emmart 1940). Several of these plants were tested and many were found to correlate with the curative properties described by the Aztec informants (Ortiz de Montellano 1975).

\section{Poisons}

Poisons are also likely to have been used in the deep past. Several plants from the Paleolithic assemblages analyzed by
Hardy (2019) were poisonous as well as medicinally valuable (Fig. 4), though it is not possible to determine whether they were used as poisons, medicines, or both since the difference is based on the dosage (Stark 2017), something that cannot be reproduced from archeological contexts. The only way to identify the probable use of a plant as poison, rather than medicine, is by its context. Traces of Ricinus communis L., Euphorbiaceae (castor oil plant), were detected on a wooden stick similar to those used recently by the Kalahari San as poisons applicators, at the $24.5 \mathrm{ka}$ archeological site of Border Cave in South Africa strongly suggesting it was being used as a poison (d'Errico et al. 2012) while traces of Euphorbia tirucalli L, Euphorbiaceae, another poisonous plant, were also found at the site (Borgia 2019). This plant is well known to contain irritant, cytotoxic, and tumorpromoting constituents such as phorbol ester derivatives found in the latex as 12-O-tetradecanoylphorbol-13-acetate (8). The arrowheads and spear points that were developed by ancient modern humans appear in the archeological record from around 70,000-50,000 years ago. They suggest throwing weapons, enabling hunters to kill without being in direct contact with the animal; however, the stone tips were not strong or large enough to kill most animals and poison is likely to have been applied to the stone tips (Borgia 2019).

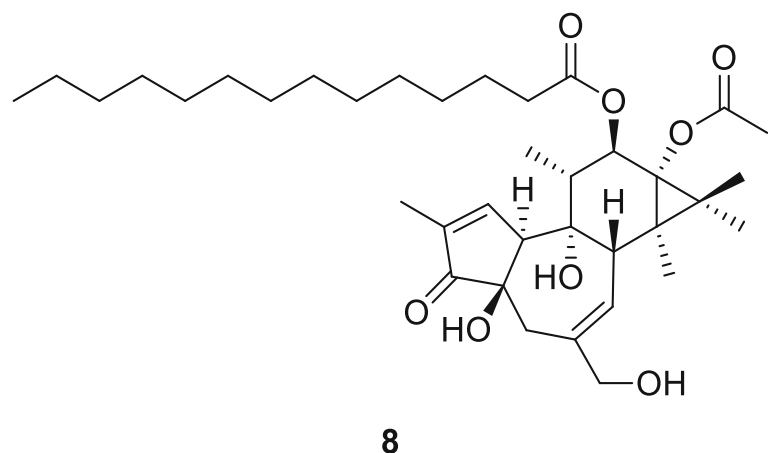

\section{Psychotropic Plants}

The use of psychotropic plants rich in entheogens or psychoactive substances may have developed out of the evolutionary use of medicinal plants since the physiological pathways to process these compounds are the same as those used for medicinal plants. These pathways are likely to be very ancient and combine taste receptors, tissue barriers, and the bloodbrain barrier (Sullivan and Hagen 2002; Hagen and Tushingham 2019). However, archeological evidence for psychotropic drug use in the Paleolithic is limited. Currently the earliest potential evidence comes from a 13,000-year-old site in Timor where the remains of betel vine (Areca catechu L., Arecaceae) were found (Hagen and Tushingham 2019). Redbrown-stained teeth, also demonstrating the use of betel nut, 
were recovered from sites in the Philippines and Vietnam dated to the 3rd millennium BC (Bronze Age) (Guerra-Doce 2015). The evidence for psychoactive plant use is more abundant in the Neolithic and also the Egyptian New Kingdom (Merlin 2003) with evidence in the form of carbonized remains of the actual plants and also as residual traces inside ceramic pots and impressions in the clay or, in Egypt, also displayed on artifacts (Merlin 2003). The presence of Cannabis has been identified as hemp imprints on pottery from Taiwan (10,000 years BP) and is present as a raw material (hemp) in early farming contexts in China (Guerra-Doce 2015) but the most common plant is Papaver somniferum L., Papaveraceae, found primarily in many later prehistoric sites from the 6th millennium BC onwards across Europe, and in Egypt from the new Kingdom (18th Dynasty, 1550-1350 BC) (Merlin 2003). Chemical analysis of organic residues found in a bundle interpreted as representing a leather bag was recovered from the Sora valley, in south west Bolivia. A range of items were identified, leading to the interpretation that this artifact had been "ritual bundle" (Miller et al. 2019) since it contained extensive evidence for plants with psychoactive properties together with snuffing tablets, a snuffing tube, and other materials. The authors suggest this bundle may have belonged to a shaman.

Drug-induced altered state of consciousness has been argued to be responsible for some of the Upper Paleolithic art, notably the geometric patterns that are found in southern Europe (Lewis-Williams et al. 1988) though this has been disputed due to the lack of indigenous plants in Europe that can cause these specific drug-induced effects and the absence of any archeological evidence for the one European fungus Claviceps purpurea (Fr.) Tul., Clavicipitaceae, able to produce this type of trance (Guerra-Doce 2015). Members of the Solanaceae, the nightshades, have been found in archeological sites in China and the New World. For example, the thorn apple, jimsonweed (jimson weed) or devil's snare (Datura stramonium L.), thought to be native to America, has been used both in traditional medicine and recreationally over the centuries; the active agents are tropane alkaloids as atropine (9), which is an enantiomeric mixture of D-hyoscyamine and L-hyoscyamine, with most of its physiological effects due to L-hyoscyamine (Al 2014).

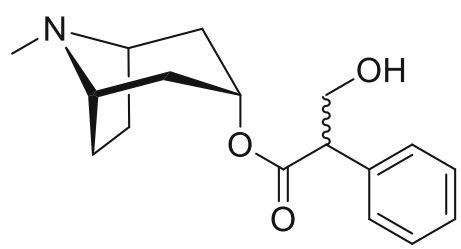

9

Most of the remaining archeological evidence for psychotropic drugs is found in the New World. These include the mescal bean, Sophora secundiflora (Ortega) Lag. ex DC., Fabaceae, and peyote, Lophophora williamsii (Lem. ex Salm-Dyck) J.M. Coult., Cactaceae, from the 9th millennium BC (Adovasio and Fry 1976), members of the coca family (Erythroxylaceae) in association with calcite (that brings out the alkaloids) from at least 8000 years ago (Dillehay et al. 2010), tobacco (Nicotiana sp., Solanaceae), yopo (Anadenanthera peregrina (L.) Speg., Fabaceae) (GuerraDoce 2015) and manufacture of ayahuasca made out of the vine Banisteriopsis caapi (Spruce ex Griseb.) C.V. Morton, Malpighiaceae, and the shrub Psychotria viridis Ruiz \& Pav., Rubiaceae (Ogalde et al. 2007, 2009).

\section{Evolutionary Context}

Detecting deliberate self-medication in past populations can be challenging, yet the archeological evidence for cured ailments and medicinal plants that cover a wide range of both curative and invasive practices and treatments suggests a high level of confidence and medicinal knowledge deep into human evolutionary time. Beyond this, the increasing evidence for self-medication among animals, insects, and also birds (Clayton et al. 2010) suggests that self-medication is a shared evolutionary behavior that stretches well beyond recent human evolution (Lozano 1998; Huffman 2003). It is well established that when they are in their known environment, animals are able to maintain themselves and their offspring in good health by selecting the "right" things to eat, including those specifically chosen to address a health problem and there are many anecdotal examples of animals using plants to self-medicate (Engel 2003; Huffman 2016). The concept of animal self-medication, or zoopharmacognosy, was first developed by Rodriguez and Wrangham (1993). Since then, evidence for self-medication has expanded significantly while it has recently been suggested that animal selfmedication practices may help to discover new potential drugs for humans (Domínguez-Martín et al. 2020).

Diseases caused by pathogens and parasites are common and many animals and insects alter their diet in response to parasite attack and also to enhance their reproductive capabilities in preparation for mating (e.g., Carrai et al. 2003; Singer et al. 2009). Studies on insects that have demonstrated both prophylactic and therapeutic consumption need to demonstrate adaptive plasticity; in other words, it must impose a fitness cost to confirm behavior as medicinal (Abbott 2014). Insects as distant from each other as fruit flies (de Roode et al. 2013), caterpillars (Singer et al. 2009), honey-bees (SimoneFinstrom and Spivak 2012; Gherman et al. 2014; Erler and Moritz 2016), monarch butterflies (Lefèvre et al. 2012), and the African armyworm (Spodoptera exempta) (Povey et al. 2014) all demonstrate some form of self-medication primarily based around reproductive status and parasite infestations. Specific studies have been documented on self-medication 
in ruminants (Lisonbee et al. 2009; Villalba et al. 2014) and elephants (Dubost et al. 2019; Greene et al. 2020).

Possibly the most numerous studies have been conducted on non-human primates. This is particularly relevant for human evolution since humans and non-human primates share a common evolutionary history and have a similar physiology and it is possible that they share ways to combat diseases through medicinal plant use (Huffman 2016). This includes studies of chimpanzees (Pan troglodytes) and gorillas (Gorilla gorilla) (Basabose 2002; Cousins and Huffman 2002; Rogers et al. 2004; Huffman 2001, 2003, 2015; Huffman and Seifu 1989; Huffman et al. 1996; Mclennan and Huffman 2012; Krief et al. 2006; Masi et al. 2012), Japanese macaques (Macaca fuscata) (Huffman et al. 2010; Tasdemir et al. 2020), sifakas (Propithecus verreauxi verreauxi) (Carrai et al. 2003), lemurs (Eulemur rufifrons) (Peckre et al. 2018), Tibetan macaques (Macaca thibetana) (Huffman et al. 2020), and orangutans (Pongo pygmaeus) (Morrogh-Bernard et al. 2017). Some of these studies have demonstrated both health maintenance and deliberate self-medication that is processed using a combination of innate mechanisms, individual learning, and cultural transmission (Huffman 2016). In all recorded cases, the plants used have been subjected to pharmacological analyses that have identified specific properties that correspond with the use of the plant. In addition to the use of plants in treatment, there are many examples of the use of foodmedicines, or medicinal foods, plants that are eaten as food, but that also contain important medicinal properties and therefore provide an underlying protection, with specific food items added in particular, in relation to parasite infection and reproductive events, though Huffman et al. (2020) have identified the use of Epimedium davidii Franch, Berberidaceae, potentially as a means of stress reduction in a preliminary study on Tibetan macaques. Icariin (10), a major prenylated flavonol glycoside, is the active principle associated with stress reduction and anti-depressant properties via downregulation of glucocorticoid receptor activity and regulation of hippocampal neuroinflammation (Li et al. 2015).

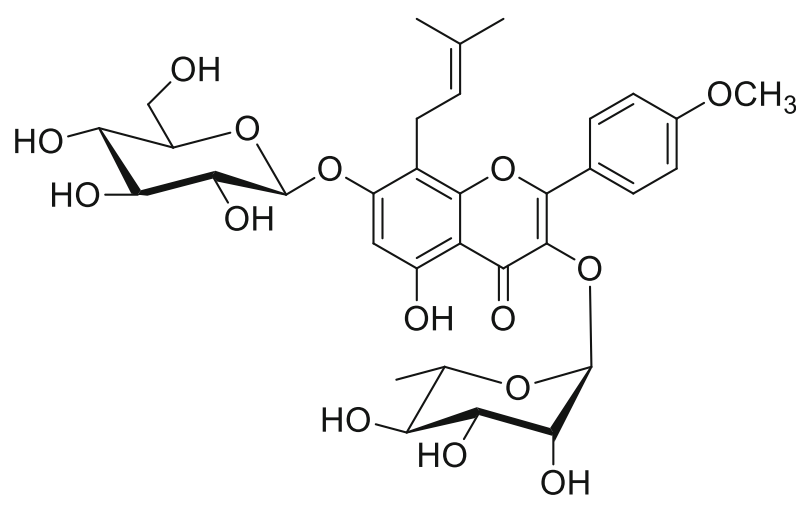

10

Chimpanzees display botanical knowledge when selecting plants (Janmaat et al. 2013) and also know the plant's location, when and how much to eat, the correct part of the plant and, at times, how to prepare it prior to ingestion (Huffman 2003; Cousins and Huffman 2002; Huffman and Seifu 1989; Huffman et al. 1996). Of the 200-300 species of plant that they habitually use in their diet, at least 36 are medicinal (Huffman 2001) while some of the best studied self-medication practices in animals are in the way chimpanzees deal with intestinal parasites. Exhaustive study has demonstrated the use of two different methods, using plants that are not necessarily an everyday part of the diet (Huffman 2016; Huffman and Seifu 1989; Huffman et al. 1996, 2016). Bitter pith chewing treats intestinal nematode infections and gastrointestinal problems while leaf swallowing addresses the problem of adult nodular worms and tapeworms (Huffman 2016). In bitter pith chewing, the outer bark and leaves of the plant Vernonia amygdalina Delile, Asteraceae, are removed, the bitter juice contained in the inner pith is then chewed, and the remaining fibrous material is spat out. This member of the daisy family is not abundant and is searched out for consumption only when a chimpanzee is ill. Following the bitter pith chewing, chimpanzees invariably improve (Huffman and Seifu 1989; Huffman et al. 1996, 2016). The biochemical properties of $V$. amygdalina consist of a range of medicinally useful chemicals while laboratory testing demonstrated the efficacy of the plant, which is also well known and used by local human populations for its medicinal properties as a treatment for intestinal parasites, stomach upsets and malaria (Huffman 2016). Leaf swallowing involves the physical expulsion of worms through increased gut action (motility) which is caused by the selection and swallowing of whole, rough leaves (Huffman et al. 1996). Leaves from over 40 different plant species are used; the main common property of the leaves is that they have silicate hairs that "catch" the worms. The leaves are eaten in a particular way, they are folded in the mouth and swallowed without chewing, normally on an empty stomach. This inhibits digestion and the leaves are normally flushed out, with attached parasites, within $6 \mathrm{~h}$ (Huffman et al. 1996, 2016).

Though currently parasite expulsion is the best-known reason to self-medicate for many species, the diversity of bioactive components found in many plant items ingested suggests that a wide range of illnesses might be treated (Huffman 2001, 2003; Cousins and Huffman 2002; Krief et al. 2006; Masi et al. 2012). Based on the assumption that anything a chimpanzee can do today was within the capabilities of the chimpanzee-human last common ancestor (McGrew 2010), the behavior of chimpanzees and bonobos is sometimes used to investigate aspects of human evolution (Hernandez-Aguilar 2009; McGrew 2010; Carvalho et al. 2012). This provides a broad evolutionary backdrop and context within which our ancestral use of medicinal plants sits comfortably; indeed, when viewed from an evolutionary perspective, it is inconceivable that hominins would have abandoned this very advantageous behavior and it is unlikely, given the constant 
battle against parasites and pathogens of all types that animals including humans experience, that they would have survived without the ability to treat at least some of these.

A long-term study of Japanese macaques has recorded several instances of cultural transmission that illustrate how new behaviors are introduced into a group (Huffman et al. 2010). As hominins spread into new environments, and as these environments changed with the huge climatic shifts that occurred in the Pleistocene, some knowledge will have been lost and potentially relearned, at times by copying animals (Huffman 2016), while a combination of population-level neophobia-neophilia may have assisted in extending knowledge in new environments with unknown plants, as populations spread geographically and climates changed (Hardy 2018). Cultural and social transmission is well established in some primate populations while there is a notable increase in specifically medicinal (and potentially poisonous) plants among humans at the start of the Neolithic (Fig. 4) most probably due to more extensive social networks (Hardy 2018). Awareness of the value of animal self-medication practices has been recorded since antiquity (Álvaro et al. 2019) and there are many examples of humans copying animal behavior in the use of medicinal plants, following observation of sick animals (Huffman 2016) while Greene et al. (2020) outline shared knowledge of medicative plants between elephants and their mahouts. A recent example of the reverse, human-animal adaptation, has also been observed in the emerging use of soap by ring-tailed coati (Nasua nasua) that live near a tourist complex on Ilha do Campeche, Brazil (Gasco et al. 2016). A good example of human-animal correlation can be found in orangutans collecting leaves of Dracaena cantleyi Baker, Asparagaceae, that they mix with saliva and rub onto parts of the body, something that is also done by the local indigenous population, who rub a poultice of this plant on parts of the body to relieve pain (Morrogh-Bernard et al. 2017).

Dogs are the first animals to have been domesticated by humans, around 32,000 years ago. Since then, they have experienced similar environments. This has led to a set of overlapping genes including some involved in the digestion process, some involved in cancer development, and some involved in the neurological process (Wang et al. 2013). Common genes are linked to aggressive behavior, depression, autism, and compulsive disorders, and dogs respond similarly to some anti-depressant drugs used to treat humans (Wang et al. 2013).

The very widespread use of medicinal plants among animals and the complex behavior associated with this supports the perspective that it is part of broad animal behavior with a long evolutionary pathway. The most likely scenario is that self-medication formed a part of the human evolutionary package and was carried throughout our long-term past. Assuming the same level of expertise among Paleolithic populations as is evident today in chimpanzees should be an absolute minimum in terms of self-medication practices and use of medicinal plants.

\section{Conclusions}

The use of plant secondary compounds as medicine is widespread in animals, insects, and even birds and has been closely studied, in particular in non-human primate species. The extent of animal self-medication to combat parasites and in reproductive fitness suggests this evolutionarily advantageous behavior will also have been practiced by our direct hominin ancestors as an essential mechanism for survival rather than being a "modern" human development. Homo sapiens emerged in the Paleolithic and apart from some recent genetic adaptations (Liebert et al. 2017), humans today are physiologically identical. Recent archeological evidence supported by historical and ethnographic data shows that a broad consumption of plants with both nutritive and medicinal compounds, in other words food-medicine, were and often still are one and the same in non-industrialized communities. In the West, the split between food and medicine that began in the Middle Ages with the suppression of entheogenic drugs (Kennedy 2014) is now perhaps starting to turn full circle as foods that also incorporate health benefits is emerging as a counter culture to the North American "fast food" diet.

The vast knowledge of medicinal, poisonous, and psychotropic plants known to be used by recent and modern nonindustrialized communities represents the relict survival of our deep evolutionary inheritance, a very ancient knowledge system known today as traditional ecological knowledge (TEK), which developed during the Paleolithic as humans developed their knowledge and repertoire, most probably, at times, copying animals in their uses of specific medicinal plants. Evidence for the confident use of plants that can be poisonous, either as medicines or directly as poisons, perhaps exemplifies more than anything else the very refined levels of cognition of these Paleolithic populations (Chaboo et al. 2019), as the line between mortal toxicity and valuable medicine can be very thin. Throughout the Paleolithic and beyond, humans developed their knowledge and built on their use of medicinal properties to apply plant secondary compounds as poisons and hallucinogens. The development and knowledge of psychotropic plants is likely to have developed out of the use of plants with medicinal properties, since the extensive evidence for the use of these among animals suggests a far greater antiquity. At some point in the past, knowledge of the medicinal and psychotropic properties of plants, which may have represented highly specialized knowledge, merged and developed into what today is called shamanism (Hardy 2019).

It is all too easy to imagine, from our current state of generally degraded ecological knowledge that traditional ecological knowledge is a recent phenomenon. Once edible plant 
sources began to be controlled in the Neolithic, the deep understanding of wild plants and particularly those that provided the essential carbohydrates will have begun to erode, as this ecological knowledge was gradually replaced with the new technological and social expertise required for sedentary, communal living. Over time, the use of wild plants is likely to have become more focused (as seen in Fig. 4) and expanded, through the knowledge of plant secondary compounds and their uses, as medicines, poisons, and hallucinogens as well as for their properties as flavorings and aromas, that have led to the modern cultural diversity and regional cuisines. As such, human development since the emergence of farming and its associated features, including storage, accumulation, new technologies, and the concentration of people into villages, then cities, should be seen as a trade-off rather than a linear advancement, as the loss of TEK and the profound understanding of the natural world and the symbioses that enable it to function, that we needed to survive and evolve as hunter gatherers, has gradually been eroded.

Acknowledgments The author would like to thank the journal editors for their constructive comments in relation to the biological activity of some secondary metabolites mentioned in the text. Thanks to Albert Zink for supplying Fig. 5

\section{References}

Abbott J (2014) Self-medication in insects: current evidence and future perspectives. Ecol Entomol 39:273-280. https://doi.org/10.1111/ een. 12110

Adovasio JM, Fry GF (1976) Prehistoric psychotropic drug use in northeastern Mexico and Trans-Pecos Texas. Econ Bot 30:94-96. https:// doi.org/10.1007/BF02866788

Al B (2014) The source-synthesis-history and use of atropine. Eur J Emerg Med 13:2-3. https://doi.org/10.5152/jaem.2014.1120141

Alt KW, Jeunesse C, Buitrago-Téllez CH, Wächter R, Boës E, Pichler SL (1997) Evidence for stone age cranial surgery. Nature 387:360-360. https://doi.org/10.1038/387360a0

Álvaro MM, Luis RR, de Lollano S, Joaquin P (2019) The origins of zoopharmacognosy: how humans learned about self-medication from animals. Int J Appl Res 5:73-79

Basabose AK (2002) Diet composition of chimpanzees inhabiting the montane forest of Kahuzi, Democratic Republic of Congo. Am J Primatol 58:1-21. https://doi.org/10.1002/ajp.10049

Benedictow OJ, Benedictow OL (2004) The Black Death, 1346-1353: The Complete History. Boydell \& Brewer, Woodbridge

Bloomfield M (1899) Atharvaveda. KJ Trübner

Borgia V (2019) The prehistory of poison arrows. In: Wexler P (ed) Toxicology in antiquity. Academic Press, Cambridge, pp 1-10. https://doi.org/10.1016/B978-0-12-815339-0.00001-9

Braje TJ, Dillehay TD, Erlandson JM, Klein RG, Rick TC (2017) Finding the first Americans. Science 358:592-594. https://doi.org/10.1126/ science.aao5473

Buckley S, Usai D, Jakob T, Radini A, Hardy K (2014) Dental calculus reveals evidence for food, medicine, cooking and plant processing in prehistoric Central Sudan. PLoS One 9:e100808. https://doi.org/10. 1371/journal.pone.0100808
Buquet-Marcon C, Philippe C, Anaick S (2007) The oldest amputation on a Neolithic human skeleton in France. Nat Precedings. https://doi. org/10.1038/npre.2007.1278.1

Bussmann RW, Sharon D (2006) Traditional medicinal plant use in Northern Peru: tracking two thousand years of healing culture. J Ethnobiol Ethnomed 2:47. https://doi.org/10.1186/1746-4269-2-47

Carrai V, Borgognini-Tarli SM, Huffman MA, Bardi M (2003) Increase in tannin consumption by sifaka (Propithecus verreauxi verreauxi) females during the birth season: a case for self-medication in prosimians? Primates 44:61-66. https://doi.org/10.1007/s10329-0020008-6

Carvalho S, Biro D, Cunha E, Hockings K, McGrew WC, Richmond BG, Matsuzawa T (2012) Chimpanzee carrying behaviour and the origins of human bipedality. Curr Biol 22:R180-R181. https://doi.org/ 10.1016/j.cub.2012.01.052

Cavalieri S, Rotoli M (1997) Huangdi Neijing: a classic book of traditional Chinese medicine. Recenti Prog Med 88:541-546

Chaboo CS, Hitchcock RK, Bradfield J, Wadley L (2019) Beetle and plant arrow poisons of the San People of Southern Africa. In: Wexler P (ed) Toxicology in antiquity, history of toxicology and environmental health, $2 \mathrm{dn}$ edn. Academic Press, Cambridge, pp 1171. https://doi.org/10.1016/B978-0-12-815339-0.00002-0

Clayton DH, Koop JA, Harbison CW, Moyer BR, Bush SE (2010) How birds combat ectoparasites. Open Ornithol J 3:41-71. https://doi. org/10.2174/1874453201003010041

Cousins D, Huffman MA (2002) Medicinal properties in the diet of gorillas: an ethno-pharmacological evaluation. Afr Stud Monogrs 23: 65-89

d'Errico F, Backwell L, Villa P, Degano I, Lucejko JJ, Bamford MK, Higham TF, Colombini MP, Beaumont PB (2012) Early evidence of San material culture represented by organic artifacts from Border Cave, South Africa. Proc Natl Acad Sci 109:13214-13219. https:// doi.org/10.1073/pnas.1204213109

de Miranda Chaves SA, Reinhard KJ (2006) Critical analysis of coprolite evidence of medicinal plant use, Piauí, Brazil. Palaeogeogr Palaeoclimatol Palaeoecol 237:110-118. https://oi.org/10.1016/j. palaeo.2005.11.031

de Roode JC, Lefèvre T, Hunter MD (2013) Self-medication in animals. Science 340:150-151. https://doi.org/10.1126/science.1235824

Dennell R (2020) From Arabia to the Pacific. How our species colonised Asia. Routledge, Abingdon, p 366

Dillehay TD (1997) Monte Verde: a Late Pleistocene settlement in Chile, vol. 2. Smithsonian, p 1071

Dillehay TD, Ramírez C, Pino M, Collins MB, Rossen J, Pino-Navarro JD (2008) Monte Verde: seaweed, food, medicine, and the peopling of South America. Science 320:784-786. https://doi.org/10.1126/ science. 1156533

Dillehay TD, Rossen J, Ugent D, Karathanasis A, Vásquez V, Netherly PJ (2010) Early Holocene coca chewing in northern Peru. Antiquity 84:939-953. https://doi.org/10.1017/S0003598X00067004

Dillehay TD, Ocampo C, Saavedra J, Sawakuchi AO, Vega RM, Pino M, Collins MB, Scott Cummings L, Arregui I, Villagran XS, Hartmann GA (2015) New archaeological evidence for an early human presence at Monte Verde, Chile. PLoS One 10:e0141923. https://doi. org/10.1371/journal.pone.0141923

Domínguez-Martín EM, Tavares J, Ríjo P, Díaz-Lanza AM (2020) Zoopharmacology: a way to discover new cancer treatments. Biomolecules 10:817. https://doi.org/10.3390/biom10060817

Douka K, Slon V, Jacobs Z, Ramsey CB, Shunkov MV, Derevianko AP, Mafessoni F, Kozlikin MB, Li B, Grün R, Comeskey D (2019) Age estimates for hominin fossils and the onset of the Upper Palaeolithic at Denisova Cave. Nature 565(7741):640-644

Dubost JM, Lamxay V, Krief S, Falshaw M, Manithip C, Deharo E (2019) From plant selection by elephants to human and veterinary pharmacopeia of mahouts in Laos. J Ethnopharmacol 244:112157. https://doi.org/10.1016/j.jep.2019.112157 
Elhadef K, Smaoui S, Fourati M, Ben Hlima H, Chakchouk Mtibaa A, Sellem I, Ennouri K, Mellouli L (2020) A review on worldwide Ephedra history and story: from fossils to natural products mass spectroscopy characterization and biopharmacotherapy potential. Evid Based Complement Alternat Med 2020:1-22. https://doi.org/ $10.1155 / 2020 / 1540638$

Emmart EW (1940) The Badianus Manuscript (Codex Barberini, Latin 241). An Aztec Herbal of 1552 . The Johns Hopkins Press, Baltimore

Engel C (2003) Wild health: lessons in natural wellness from the animal kingdom. Houghton Mifflin Harcourt, New York

Erler S, Moritz RF (2016) Pharmacophagy and pharmacophory: mechanisms of self-medication and disease prevention in the honeybee colony (Apis mellifera). Apidologie 47:389-411. https://doi.org/ 10.1007/s13592-015-0400-Z

Faria MA (2015) Neolithic trepanation decoded-a unifying hypothesis: has the mystery as to why primitive surgeons performed cranial surgery been solved? Surg Neurol Int 6:72. https://doi.org/10. 4103/2152-7806.156634

Frayer DW, Gatti J, Monge J, Radovčić D (2017) Prehistoric dentistry? P4 rotation, partial M3 impaction, toothpick grooves and other signs of manipulation in Krapina Dental Person 20. Bull Int Assoc Paleodont 11:1-10

Frey EF (1985) The earliest medical texts. Clio Med 20:79-90. https:// doi.org/10.1163/9789004418295 004

Gaber O, Künzel KH (1998) Man from the Hauslabjoch. Exp Gerontol 33:655-660. https://doi.org/10.1016/S0531-5565(98)00048-5

Gasco AD, Pérez-Acosta AM, Monticelli PF (2016) Ring-tailed coatis anointing with soap: a new variation of self-medication culture? Int J Comp Psychol 29(1). Retrieved from https://escholarship.org/uc/ item $/ 1 \mathrm{dq} 4 \mathrm{~s} 4 \mathrm{p} 5$

Gherman BI, Denner A, Bobiș O, Dezmirean DS, Mărghitaș LA, Schluens H, Moritz RF, Erler S (2014) Pathogen-associated selfmedication behavior in the honeybee Apis mellifera. Behav Ecol Sociobiol 68:1777-1784. https://doi.org/10.1007/s00265-0141786-8

Gracia-Téllez A, Arsuaga JL, Martínez I, Martín-Francés L, MartinónTorres M, de Castro JMB, Bonmatí A, Lira J (2013) Orofacial pathology in Homo heidelbergensis: the case of Skull 5 from the Sima de los Huesos site (Atapuerca, Spain). Quat Int 295:83-93. https:// doi.org/10.1016/j.quaint.2012.02.005

Greene AM, Panyadee P, Inta A, Huffman MA (2020) Asian elephant self-medication as a source of ethnoveterinary knowledge among Karen mahouts in northern Thailand. J Ethnopharmacol 259: 112823. https://doi.org/10.1016/j.jep.2020.112823

Guerra-Doce E (2015) Psychoactive substances in prehistoric times: examining the archaeological evidence. Time Mind 8:91-112. https:// doi.org/10.1080/1751696X.2014.99324

Hagen EH, Tushingham S (2019) The prehistory of psychoactive drug use. In: Henley TB, Rossano MJ, Kardas EP (eds) Handbook of cognitive archaeology: psychology in prehistory. Routledge, New York. https://doi.org/10.4324/9780429488818-25

Hardy K (2018) Plant use in the Lower and Middle Palaeolithic: food, medicine, and raw materials. Quat Sci Rev 191:393-405. https://doi. org/10.1016/j.quascirev.2018.04.028

Hardy K (2019) Paleomedicine and the use of plant secondary compounds in the Paleolithic and Early Neolithic. Evol Anthropol 28: 60-71. https://doi.org/10.1002/evan.21763

Hardy K, Buckley S, Collins MJ, Estalrrich A, Brothwell D, Copeland L, García-Tabernero A, García-Vargas S, Rasilla M, Lalueza-Fox C, Huguet R, Bastir M, Santamaría D, Madella M, Wilson J, Cortés ÁF, Rosas A (2012) Neanderthal medics? Evidence for food, cooking and medicinal plants entrapped in dental calculus. Naturwissenschaften 99(8):617-626. https://doi.org/10.1007/ s00114-012-0942-0
Hardy K, Buckley S, Huffman M (2013) Neanderthal self-medication in context. Antiquity 87:873-878. https://doi.org/10.1017/ S0003598X00049528

Hardy K, Buckley S, Huffman M (2016) Doctors, chefs or hominin animals? Non-edible plants and Neanderthals. Antiquity 90:13731379. https://doi.org/10.15184/aqy.2016.134

Hardy K, Radini A, Buckley S, Blasco R, Copeland L, Burjachs F, Girbal J, Yll R, Carbonell E, Bermudez de Castro J (2017) Diet and environment 1.2 million years ago revealed through analysis of dental calculus from Europe's oldest hominin at Sima del Elefante, Spain. Sci Nat 104. https://doi.org/10.1007/s00114-016-1420-x

Hernandez-Aguilar RA (2009) Chimpanzee nest distribution and site reuse in a dry habitat: implications for early hominin ranging. J Hum Evol 57:350-364. https://doi.org/10.1016/j.jhevol.2009.03.007

Higham T, Douka K, Wood R, Ramsey CB, Brock F, Basell L, Camps M, Arrizabalaga A, Baena J, Barroso-Ruíz C, Bergman C (2014) The timing and spatiotemporal patterning of Neanderthal disappearance. Nature 512:306-309. https://doi.org/10.1038/nature13621

Huffman MA (2001) Self-medicative behavior in the African great apes: an evolutionary perspective into the origins of human traditional medicine. BioScience 51:651-661. https://doi.org/10.1641/00063568(2001)051[0651:SMBITA]2.0.CO;2

Huffman MA (2003) Animal self-medication and ethno-medicine: exploration and exploitation of the medicinal properties of plants. Proc Nut Soc 62:371-381. https://doi.org/10.1079/PNS2003257

Huffman MA (2015) Chimpanzee self-medication: a historical perspective of the key findings. In, Nakamura, M., Hosaka, K., Itoh, N. and Zamma, K. (Eds.), 2015. Mahale Chimpanzees: 50 Years of Research. Cambridge University Press, Cambridge, 50:340-353.

Huffman MA (2016) An ape's perspective on the origin of medicinal plant use in humans. In: Hardy K, Kubiak Martens L (eds) Wild harvest: plants in the Hominin and pre-agrarian human worlds. Oxbow books, Oxford, pp 55-70

Huffman MA, Seifu M (1989) Observations on the illness and consumption of a possibly medicinal plant Vernonia amygdalina (Del.), by a wild chimpanzee in the Mahale Mountains National Park, Tanzania. Primates 30:51-63. https://doi.org/10.1007/BF02381210

Huffman MA, Page JE, Sukhdeo MV, Gotoh S, Kalunde MS, Chandrasiri T, Towers GN (1996) Leaf-swallowing by chimpanzees: a behavioral adaptation for the control of strongyle nematode infections. Int J Primatol 17:475-503. https://doi.org/10.1007/ BF02735188

Huffman MA, Leca JB, Nahallage CA (2010) Cultured Japanese macaques: a multidisciplinary approach to stone handling behavior and its implications for the evolution of behavioral tradition in nonhuman primates. In: Nakagawa N, Nakamichi M, Sugiura H (eds) The Japanese macaques. Primatology Monographs, vol 0. Springer, Tokyo. https://doi.org/10.1007/978-4-431-53886-8_9

Huffman MA, Sun BH, Li JH (2020) Medicinal properties in the diet of Tibetan macaques at Mt. Huangshan: a case for self-medication. In: Li J-H, Sun L, Kappeler P (eds) The behavioral ecology of the Tibetan macaque. Fascinating Life Sciences. Springer, Cham. https://doi.org/10.1007/978-3-030-27920-2_12

Hulkower R (2016) The history of the Hippocratic Oath: outdated, inauthentic, and yet still relevant. Einstein J Biol Med 25:41-44

Humphrey LT, De Groote I, Morales J, Barton N, Collcutt S, Ramsey CB, Bouzouggar A (2014) Earliest evidence for caries and exploitation of starchy plant foods in Pleistocene hunter-gatherers from Morocco. Proc Natl Acad Sci 111:954-959. https://doi.org/10. 1073/pnas.1318176111

Janmaat KR, Ban SD, Boesch C (2013) Taï chimpanzees use botanical skills to discover fruit: what we can learn from their mistakes. Anim Cogn 16:851-860. https://doi.org/10.1007/s10071-013-0617-z

Johns T (1990) With bitter herbs shall they eat it: chemical ecology and the origin of human diet and medicine. University of Arizona Press, Tucson, p 367 
Kennedy DO (2014) Plants and the human brain. Oxford University Press, Oxford

Khojaste M, Yazdanian M, Tahmasebi E, Shokri M, Houshmand B, Shahbazi R (2018) Cell toxicity and inhibitory effects of Cyperus rotundus extract on Streptococcus mutans, Aggregatibacter actinomycetemcomitans and Candida albicans. Eur J Trans1 Myol 28:7917. https://doi.org/10.4081/ejtm.2018.7917

Krief S, Huffman MA, Sévenet T, Hladik CM, Grellier P, Loiseau PM, Wrangham RW (2006) Bioactive properties of plant species ingested by chimpanzees (Pan troglodytes schweinfurthii) in the Kibale National Park, Uganda. Am J Primatol 68:51-71. https:// doi.org/10.1002/ajp.20206

Lefèvre T, Chiang A, Kelavkar M, Li H, Li J, de Castillejo CL, Oliver L, Potini Y, Hunter MD, de Roode JC (2012) Behavioural resistance against a protozoan parasite in the monarch butterfly. J Anim Ecol 81:70-79. https://doi.org/10.1111/j.1365-2656.2011.01901.x

Leles D, Reinhard KJ, Fugassa M, Ferreira LF, Iñiguez AM, Araújo A (2010) A parasitological paradox: why is ascarid infection so rare in the prehistoric Americas? J Archaeol Sci 37:1510-1520. https://doi. org/10.1016/j.jas.2010.01.011

Leroi-Gourhan A (1975) The flowers found with Shanidar IV, a Neanderthal burial in Iraq. Scice 190:562-564. https://doi.org/10. 1126/science.190.4214.562

Lewis-Williams JD, Dowson TA, Bahn PG, Bandi HG, Bednarik RG, Clegg J, Consens M, Davis W, Delluc B, Delluc G, Faulstich P, Halverson J, Layton T, Martindale C, Mirimanov V, Turner CG II, Vastokas JM, Winkelman M, Wylie A (1988) The signs of all times: entoptic phenomena in Upper Palaeolithic art [and comments and reply]. Curr Anthropol 29:201-245. https://doi.org/10.2307/ 2743395

Li C, Li Q, Mei Q, Lu T (2015) Pharmacological effects and pharmacokinetic properties of icariin, the major bioactive component in Herba Epimedii. Life Sci 126:57-68. https://doi.org/10.1016/j.lfs.2015.01. 006

Liebert A, López S, Jones BL, Montalva N, Gerbault P, Lau W, Thomas MG, Bradman N, Maniatis N, Swallow DM (2017) World-wide distributions of lactase persistence alleles and the complex effects of recombination and selection. Hum Genet 136:1445-1453. https:// doi.org/10.1007/s00439-017-1847-y

Lillie MC (1998) Cranial surgery dates back to Mesolithic. Nature 391: 854. https://doi.org/10.1038/36023

Lisonbee LD, Villalba JJ, Provenza FD, Hall JO (2009) Tannins and selfmedication: implications for sustainable parasite control in herbivores. Behav Process 82:184-189. https://doi.org/10.1016/j. beproc.2009.06.009

Lordkipanidze D, Vekua A, Ferring R, Rightmire GP, Agusti J, Kiladze G, Mouskhelishvili A, Nioradze M, Ponce de León MS, Tappen M, Zollikofer CPE (2005) Anthropology: the earliest toothless hominin skull. Nature 434:717-718. https://doi.org/10.1038/434717b

Lozano GA (1998) Parasitic stress and self-medication in wild animals. Adv Study Behav 27:291-318

Lozano M, Subirà ME, Aparicio J, Lorenzo C, Gómez-Merino G (2013) Toothpicking and periodontal disease in a Neanderthal specimen from Cova Foradà site (Valencia, Spain). PLoS One 8:e76852. https://doi.org/10.1371/journal.pone.0076852

Lynch TF (1980) Guitarrero Cave: early man in the Andes. Academic Press, Cambridge

Masi S, Gustafsson E, Saint Jalme M, Narat V, Todd A, Bomsel MC, Krief S (2012) Unusual feeding behavior in wild great apes, a window to understand origins of self-medication in humans: role of sociality and physiology on learning process. Physiol Behav 105: 337-349. https://doi.org/10.1016/j.physbeh.2011.08.012

McGrew WC (2010) In search of the last common ancestor: new findings on wild chimpanzees. Philos Trans R Soc Lond Ser B Biol Sci 365: 3267-3276. https://doi.org/10.1098/rstb.2010.0067
Mclennan MR, Huffman MA (2012) High frequency of leaf swallowing and its relationship to intestinal parasite expulsion in "Village" chimpanzees at Bulindi, Uganda. Am J Primatol 74:642-650. https://doi.org/10.1002/ajp.22017

Merlin MD (2003) Archaeological evidence for the tradition of psychoactive plant use in the old world. Econ Bot 57:295-323. https://doi. org/10.2307/4256701

Mikulic M (2020) Global spending on medicines, 2020-2024. https:// www.statista.com/statistics/280572/medicine-spending-worldwide/

Miller MJ, Albarracin-Jordan J, Moore C, Capriles JM (2019) Chemical evidence for the use of multiple psychotropic plants in a 1,000-yearold ritual bundle from South America. Proc Natl Acad Sci 116: 11207-11212. https://doi.org/10.1073/pnas.1902174116

Mordechai L, Eisenberg M, Newfield TP, Izdebski A, Kay JE, Poinar H (2019) The Justinianic Plague: an inconsequential pandemic? Proc Natl Acad Sci 116:25546-25554. https://doi.org/10.1073/pnas. 1903797116

Moreno-Mayar JV, Vinner L, de Barros DP, De La Fuente C, Chan J, Spence JP, Allentoft ME, Vimala T, Racimo F, Pinotti T, Rasmussen S, Margaryan A, Orbegozo MI, Mylopotamitaki D, Wooller M, Bataille C, Becerra-Valdivia L, Chivall D, Comeskey D, Devièse T, Grayson DK, George L, Harry H, Alexandersen V, Primeau C, Erlandson J, Rodrigues-Carvalho C, Reis S, Bastos MQR, Cybulski J, Vullo C, Morello F, Vilar M, Wells S, Gregersen K, Hansen KL, Lynnerup N, Lahr MM, Kjær K, Strauss A, Alfonso-Durruty M, Salas A, Schroeder H, Higham T, Malhi RS, Rasic JT, Souza L, Santos FR, Malaspinas A-S, Sikora M, Nielsen R, Song YS, Meltzer DJ, Willerslev E (2018) Early human dispersals within the Americas. Science 362:eaav2621. https://doi.org/10.1126/science.aav2621

Morrogh-Bernard HC, Foitová I, Yeen Z, Wilkin P, De Martin R, Rárová L, Doležal K, Nurcahyo W, Olšanský M (2017) Self-medication by orang-utans (Pongo pygmaeus) using bioactive properties of Dracaena cantleyi. Sci Rep 7:16653. https://doi.org/10.1038/ s41598-017-16621-w

Nadel D, Werker E (1999) The oldest ever brush hut plant remains from Ohalo II, Jordan Valley, Israel (19,000 BP). Antiquity 73:755-764. https://doi.org/10.1017/S0003598X00065509

Ogalde J, Arriaza B, Soto E (2007) Prehistoric psychotropic consumption in Andean Chilean mummies. J Archaeol Sci. https://doi.org/10. 1038/npre.2007.1368.1

Ogalde JP, Arriaza BT, Soto EC (2009) Identification of psychoactive alkaloids in ancient Andean human hair by gas chromatography/ mass spectrometry. J Archaeol Sci 36:467-472. https://doi.org/10. 1016/j.jas.2008.09.036

Ortiz de Montellano B (1975) Empirical Aztec medicine. Science 188: 215-220. https://doi.org/10.1126/science.1090996

Oxilia G, Peresani M, Romandini M, Matteucci C, Spiteri CD, Henry AG, Schulz D, Archer W, Crezzini J, Boschin F, Boscato P (2015) Earliest evidence of dental caries manipulation in the Late Upper Palaeolithic. Sci Rep 5:12150. https://doi.org/10.1038/srep12150

Paniagua-Zambrana NY, Bussmann RW (eds.) 2020. Ethnobotany of the Andes, Ethnobotany of Mountain Regions, Springer Nature Switzerland A, pp 773-778. https://doi.org/10.1007/978-3-03028933-1 107

Peckre LR, Defolie C, Kappeler PM, Fichtel C (2018) Potential selfmedication using millipede secretions in red-fronted lemurs: combining anointment and ingestion for a joint action against gastrointestinal parasites? Primates 59:483-494. https://doi.org/10.1007/ s10329-018-0674-7

Petrone P, Niola M, Di Lorenzo P, Paternoster M, Graziano V, Quaremba G, Buccelli C (2015) Early medical skull surgery for treatment of post-traumatic osteomyelitis 5,000 years ago. PLoS One 10. https:// doi.org/10.1371/journal.pone.0124790

Povey S, Cotter SC, Simpson SJ, Wilson K (2014) Dynamics of macronutrient self-medication and illness induced anorexia in virally 
infected insects. J Anim Ecol 83:245-255. https://doi.org/10.1111/ $1365-2656.12127$

Powell JM (1976) Ethnobotany. In: Paijmans (ed) New Guinea vegetation. Australia National University Press, Canberra, pp 106-183

Prioreschi P (1996) A history of medicine: Greek medicine, vol 2. Horatius Press, Omaha

Radini A, Buckley S, Rosas A, Estalrrich A, de la Rasilla M, Hardy K (2016) Neanderthals, trees and dental calculus: new evidence from El Sidrón. Antiquity 90:290-301. https://doi.org/10.15184/aqy. 2016.21

Reich D, Green RE, Kircher M, Krause J, Patterson N, Durand EY, Viola B, Briggs AW, Stenzel U, Johnson PL, Maricic T (2010) Genetic history of an archaic hominin group from Denisova Cave in Siberia. Nature 468(7327):1053-1060

Reich D, Patterson N, Kircher M, Delfin F, Nandineni MR, Pugach I, Ko AMS, Ko YC, Jinam TA, Phipps ME, Saitou N (2011) Denisova admixture and the first modern human dispersals into Southeast Asia and Oceania. Am J Hum Genet 89(4):516-528

Reinhard K, Hamilton DL, Hevly RH (1991) Use of pollen concentration in paleopharmacology: coprolite evidence of medicinal plants. J Ethnobiol 11:117-132

Retief FP, Cilliers L (2007) Mesopotamian medicine. S Afr Med J 97:27_ 30

Ritner RK (2000) Innovations and adaptations in ancient Egyptian medicine. J Near Eas Stud 59:107-117. https://doi.org/10.2307/545610

Roberts L (1989) Disease and death in the New World. Science 246(4935): 1245

Robson E (2008) Mesopotamian medicine and religion: current debates, new perspectives. Religion Compass 2:455-483. https://doi.org/10. 1111/j.1749-8171.2008.00082.x

Rodriguez E, Wrangham R (1993) Zoopharmacognosy: the use of medicinal plants by animals. In: Downum KR, Romeo JT, Stafford HA (eds) Phytochemical potential of tropical plants. Springer, Boston, pp 89-105

Rogers ME, Abernethy K, Bermejo M, Cipolletta C, Doran D, McFarland K, Nishihara T, Remis M, Tutin CE (2004) Western gorilla diet: a synthesis from six sites. Am J Primatol 64:173-192. https://doi.org/ 10.1002/ajp.20071

Samadelli M, Melis M, Miccoli M, Vigl EE, Zink AR (2015) Complete mapping of the tattoos of the 5300-year-old Tyrolean iceman. J Cult Herit 16(5):753-758

Sankararaman S, Patterson N, Li H, Pääbo S, Reich D (2012) The date of interbreeding between Neandertals and modern humans. PLoS Genet 8:e1002947. https://doi.org/10.1371/journal.pgen.1002947

Saslis-Lagoudakis CH, Savolainen V, Williamson EM, Forest F, Wagstaff SJ, Baral SR, Watson MF, Pendry CA, Hawkins JA (2012) Phylogenies reveal predictive power of traditional medicine in bioprospecting. Proc Natl Acad Sci 109:15835-15840. https:// doi.org/10.1073/pnas.1202242109

Schumock GT, Li EC, Wiest MD, Suda KJ, Stubbings J, Matusiak LM, Hunkler RJ, Vermeulen LC (2017) National trends in prescription drug expenditures and projections for 2017. Am J Health Syst Pharm 74:1158-1173. https://doi.org/10.2146/ajhp170164

Simone-Finstrom MD, Spivak M (2012) Increased resin collection after parasite challenge: a case of self-medication in honey bees? PLoS One 7:e34601. https://doi.org/10.1371/journal.pone.0034601

Singer MS, Mace KC, Bernays EA (2009) Self-medication as adaptive plasticity: increased ingestion of plant toxins by parasitized caterpillars. PLoS One 4:e4796. https://doi.org/10.1371/journal.pone. 0004796

Singh O, Khanam Z, Misra N, Srivastava MK (2011) Chamomile (Matricaria chamomilla L.): an overview. Pharmacogn Rev 5:8295. https://doi.org/10.4103/0973-7847.79103

Sobolik KD, Gerick DJ (1992) Prehistoric medicinal plant usage: a case study from coprolites. J Ethnobiol 12:203-211
Solecki RS (1975) Shanidar IV, a Neanderthal flower burial in northern Iraq. Science 190:880-881. https://doi.org/10.1126/science.190. 4217.880

Sommer JD (1999) The Shanidar IV 'flower burial': a re-evaluation of Neanderthal burial ritual. Camb Archaeol J 9:127-129. https://doi. org/10.1017/S0959774300015249

Spikins P, Needham A, Wright B, Dytham C, Gatta M, Hitchens G (2019) Living to fight another day: the ecological and evolutionary significance of Neanderthal healthcare. Quat Sci Rev 217:98-118. https://doi.org/10.1016/j.quascirev.2018.08.011

Ssegawa P, Kasenene JM (2007) Medicinal plant diversity and uses in the Sango bay area, Southern Uganda. J Ethnopharmacol 113:521-540. https://doi.org/10.1016/j.jep.2007.07.014

Stark MC (2017) Hormesis: the difference between a poison and a medication. J Clin Exp Tox 1(1):1-2

Sullivan RJ, Hagen EH (2002) Psychotropic substance-seeking: evolutionary pathology or adaptation? Addiction 97(4):389-400

Sullivan R, Behncke I, Purushotham A (2010) Why do we love medicines so much? An evolutionary perspective on the human love of pills, potions and placebo. EMBO Rep 11:572-578. https://doi.org/10. 1038/embor.2010.108

Sun C, Xing S, Martín-Francés L, Bae C, Liu L, Wei G, Liu W (2014) Interproximal grooves on the Middle Pleistocene hominin teeth from Yiyuan, Shandong Province: new evidence for tooth-picking behavior from eastern China. Quat Int 354:162-168. https://doi.org/ 10.1016/j.quaint.2014.03.008

Tamba Y (1986) The essentials of medicine in ancient China and Japan: Yasuyori Tamba's Ishimpō (Vol. 1). Brill Archive

Tasdemir D, MacIntosh AJ, Stergiou P, Kaiser M, Mansour NR, Bickle Q, Huffman MA (2020) Antiprotozoal and antihelminthic properties of plants ingested by wild Japanese macaques (Macaca fuscata yakui) in Yakushima Island. J Ethnopharmacol 247:112270. https://doi.org/10.1016/j.jep.2019.112270

Teixeira-Santos I, Sianto L, Araújo A, Reinhard KJ, Chaves SAM (2015) The evidence of medicinal plants in human sediments from Furna do Estrago prehistoric site, Pernambuco State, Brazil. Quat Int 377: 112-117. https://doi.org/10.1016/j.quaint.2015.01.019

Trinkaus E, Zimmerman MR (1982) Trauma among the Shanidar Neandertals. Am J Phys Anthropol 57:61-76. https://doi.org/10. 1002/ajpa.1330570108

Ungar PS, Grine FE, Teaford MF, Pérez-Pérez A (2001) A review of interproximal wear grooves on fossil hominin teeth with new evidence from Olduvai Gorge. Arch Oral Biol 46:285-292. https://doi. org/10.1016/S0003-9969(00)00128-X

Verano JW (2003) Trepanation in prehistoric South America: geographic and temporal trends over 2000 years. In: Arnott R, Finger S, Smith C, Arnott FS, Smith C (eds) Trepanation: history, discovery, theory, pp 223-236

Verano JW, Anderson LS, Franco R (2000) Foot amputation by the Moche of ancient Peru: osteological evidence and archaeological context. Int J Osteoarchaeol 10:177-188. https://doi.org/10.1002/ 1099-1212(200005/06)10:3<177::AID-OA520>3.0.CO;2-O

Villalba JJ, Miller J, Ungar ED, Landau SY, Glendinning J (2014) Ruminant self-medication against gastrointestinal nematodes: evidence, mechanism and origins. Parasite 21. https://doi.org/10. 1051/parasite/2014032

Vos T, Allen C, Arora M, Barber RM, Bhutta ZA, Brown A, Carter A, Casey DC, Charlson FJ, Chen AZ, Coggeshall M (2016) Global, regional, and national incidence, prevalence, and years lived with disability for 310 diseases and injuries, 1990-2015: a systematic analysis for the Global Burden of Disease Study 2015. Lancet 388:1545-1602. https://doi.org/10.1016/S0140-6736(16)31678-6

Wagner DM, Klunk J, Harbeck M, Devault A, Waglechner N, Sahl JW, Enk J, Birdsell DN, Kuch M, Lumibao C, Poinar D (2014) Yersinia pestis and the Plague of Justinian 541-543 AD: a genomic analysis. 
Lancet Infect Dis 14:319-326. https://doi.org/10.1016/S14733099(13)70323-2

Wang GD, Zhai W, Yang HC, Fan RX, Cao X, Zhong L, Wang L, Liu F, Wu H, Cheng LG, Poyarkov AD (2013) The genomics of selection in dogs and the parallel evolution between dogs and humans. Nat Commun 4:1860. https://doi.org/10.1038/ncomms2814

Weyrich LS, Duchene S, Soubrier J, Arriola L, Llamas B, Breen J, Morris AG, Alt KW, Caramelli D, Dresely V, Farrell M, Farrer AG, Francken M, Gully N, Haak W, Hardy K, Harvati K, Held P, Holmes EC, Kaidonis J, Lalueza-Fox C, de la Rasilla M, Rosas A, Semal P, Soltysiak A, Townsend G, Usai D, Wahl J, Huson DH, Dobney K, Cooper A (2017) Neanderthal behaviour, diet, and disease inferred from ancient DNA in dental calculus. Nature 544: 357-361. https://doi.org/10.1038/nature21674

Wong KC, Wu LT (1932) History of Chinese medicine. Being a chronicle of medical happenings in China from ancient times to the present period. JAMA 108:2068. https://doi.org/10.1001/jama.1937. 02780240060029

Yu HH, Lee DH, Seo SJ, You YO (2007) Anticariogenic properties of the extract of Cyperus rotundus. Am J Chin Med 35:497-505. https:// doi.org/10.1142/S0192415X07005016

Zink A, Samadelli M, Gostner P, Piombino-Mascali D (2019) Possible evidence for care and treatment in the Tyrolean Iceman. Int $\mathbf{J}$ Paleopathol 25:110-117. https://doi.org/10.1016/j.ijpp.2018.07.006 